\title{
Biological effectiveness of quillay (Quillaja saponaria) extracts for the control of yellow aphids (Melanaphis sacchari) in sorghum
}

\author{
Ramírez-Rojas, Sergio G. ${ }^{1 *}$; Palacios-Talavera, Alejandro ${ }^{1}$; Vázquez-Alvarado, Jorge M. P. ${ }^{1}$; \\ Pérez-González, Jesús O. ${ }^{2}$; Bartolo-Reyes, Juan C. ${ }^{1}$ \\ 1 Instituto Nacional de Investigaciones Forestales, Agrícolas y Pecuarias. Campo Experimental Zacatepec. \\ Carretera Zacatepec-Galeana km 0.5, Zacatepec, Morelos, México. C. P. 62780. \\ 2 Universidad Tecnológica del Sur del Estado de Morelos. Carretera Puente de Ixtla-Mazatepec km 2.35, \\ Colonia 24 de febrero, Puente de Ixtla, Morelos, México. C. P. 62665. \\ * Correspondence: sergioinifap@yahoo.com.mx
}

Gitation: Ramírez-Rojas, S. G., Palacios-Talavera, A., VázquezAlvarado, J. M. P., Pérez-González, J. O., \& Bartolo-Reyes, Juan C. (2021). Biological effectiveness of quillay (Quillaja saponaria) extracts for the control of yellow aphids (Melanaphis sacchari) in sorghum. Agro Productividad. https://doi.org/10.32854/agrop. v14i12.1950

Editor in Chief: Dr. Jorge Cadena Iñiguez

Received: February 5, 2021. Accepted: November 19, 2021. Published on-line: December 20, 2021 .

This work is licensed under a Creative Commons Attribution-NonCommercial 4.0 International license.

\section{ABSTRACT}

Objective: To evaluate and define a plant extract for the control of the yellow aphid in order to prevent environmental contamination and improve crop profitability.

Design/Methodology/Approach: In a sorghum plot —located in the municipality of Jantetelco, Moreloswith a high incidence of yellow aphids, three doses -2-, 4-, and 6- $\mathrm{mL} \mathrm{L}^{-1}$ of water of Quillaja saponaria extract, $0.2-\mathrm{mL} \mathrm{L}^{-1}$ of water of Imidacloprid, and $10-\mathrm{mL} \mathrm{L}^{-1}$ of water of calcium polysulfide-, as well as an absolute control, were evaluated. The applications were carried out using a 15-L manual spray backpack, which had been previously calibrated and had a fan nozzle. A randomized block experimental design - with six treatments and four repetitions - was used. The experimental unit was made up of five 5-m long rows with $0.70 \mathrm{~m}$ between rows, resulting in a $17.5 \mathrm{~m}^{2}$ total area per experimental unit. The three central furrows were the useful plot, leaving $0.5 \mathrm{~m}$ at each end of the furrow. The total size of the experimental plot was $420 \mathrm{~m}^{2}$.

Results: The biological effectiveness during the samplings was as follows: both the Quillaja saponaria (6-, 4- and $2-\mathrm{mL} \mathrm{L}^{-1}$ water doses) and Imidacloprid treatments had a $100 \%$ effectiveness.

Study limitations/implications: This study was carried out in sorghum crops.

Findings/conclusions: Treatments based on Quillaja saponaria extracts on M. sacchari in sorghum crops showed $100 \%$ biological effectiveness from the first application and no phytotoxicity was observed in any treatment.

Key words: aphids, vegetable extracts, Sorghum bicolor, agroecological management.

\section{INTRODUCTION}

The yellow sorghum aphid, Melanaphis sacchari (Zehntner, 1897), is a pest that originated in Africa (Singh et al., 2004). It prefers to colonize sorghum and sugarcane (Blackmand and Eastop, 2015); however, many grown and wild poaceae can also act as a host for these aphids (Peña-Martínez et al., 2015). This insect appeared in Mexico in November 2013 (Rodríguez del Bosque and Terán, 2015), feeding from and severely damaging sorghum 
(Sorghum bicolor) in northern Tamaulipas (Mexico). These pests attacked sorghum because it is their favorite crop and Johnson Grass (Sorghum halepense) is their main alternative host. It is believed that Texas and Louisiana are the geographical origin of this infestation. This pest was apparently brought into Mexico by the movement of the winds and tropical storms and in agricultural machinery and equipment that had been used in infected areas, as well as by winged adults that flew from the United States (SENASICA, 2014).

This pest caused 30-100\% losses in Tamaulipas (Rodríguez del Bosque and Terán, 2015). The presence of yellow aphid reduces the quality sorghum forage, especially for cattle, sheep, and goats (Rodríguez del Bosque et al., 2018).

The yellow sorghum aphid appeared for the first time in Morelos in 2015, causing complete disasters with up to $50 \%$ yield losses (SIAP, 2018). The low thermic requirements it needs to complete its biological cycle mean that the yellow aphid is the only one of its kind that has a very fast reproductive stage (Setokuchi and Muta, 1993). The damage caused to sorghum by Melanaphis sacchari depends on several factors (by themselves or combined), including: population density, duration of the infestation, tolerance or susceptibility of sorghum germplasm (Singh et al., 2004; Aranda-Lara et al., 2019), presence of natural enemies of the yellow aphid - mainly predators, parasitoids, entomopathogenic fungi, virus, and bacteria - and some abiotic factors - such as temperature, relative humidity, rain, and wind (Gallou et al., 2016). The plant's phenological stage also influences the presence of the insect, although significative infestations appear during the final growth stages of the plant and during drought periods.

The insect causes direct damage to the plant suctioning the sap of its leaves; the leaves then turn brown, and consequently their growth is delayed and the crop performance is affected.

Figure 1 shows sooty mold growing on the foliage of the plants (indirect damage), affecting its photosynthetic capacity. M. sacchari can spread viruses such as the Sugarcane Mosaic Virus (SGMV), the Sugarcane Yellow Leaf Virus (ScYLV), and other diseases (SENASICA, 2014).

Since the appearance of this insect, researchers have been looking at ways to control it. Genetic resistance has been studied; however, no hybrids strong enough to resist it have been found (Aranda-Lara et al., 2019). The most efficient control has been the application of chemical products; however, these products have side effects harmful for humans, animals, and the environment. In order to prevent this situation, bioinsecticides and vegetable extracts have been proposed to fight the infestation. A Verticillium lecanii-based



Figure 1. High population of Melanaphis sacchari causing direct damage to a Sorghum bicolor leave. 
bioinsecticide has proved to be lethal to the aphid (SENASICA, 2014). During experiments, cempasúchil (Tagetes erecta) and higuerilla or castor oil plant (Ricinus communis) extracts had been able to control the nymphs of the yellow aphid (Rodríguez del Bosque et al., 2018). As a result of the promising benefits of bioinsecticides, a proposal to study the effects of quillay or soap bark tree (Quillaja saponaria) extracts on the yellow aphid (Melanaphis sacchari) and to obtain the most effective dose for the treatment was presented.

\section{MATERIALS AND METHODS}

\section{Experimental design}

A randomized block experimental design - with six treatments and four repetitionswas used. The experimental unit had five 5-m long furrows with $0.70 \mathrm{~m}$ between them, with a $17.5 \mathrm{~m}^{2}$ total area per experimental unit. The three central furrows were the useful plot, leaving $0.5 \mathrm{~m}$ at each end of the furrow. The total size of the experimental plot was $420 \mathrm{~m}^{2}$.

\section{Treatments}

The studied treatments are shown in Table 1. Quillay was chosen because it has saponin, which is a biodegradable non-volatile organic compound that works as fungicide, nematicide, and insecticide and promotes growth (Correa and Martínez, 2013). A 2-6 $\mathrm{mL} \mathrm{L}^{-1}$ range was evaluated because the dose was not determined yet. A treatment using Imidacloprid was used as commercial control, because it is the most used product in the region. Calcium polysulfide was included because the sorghum producers said that it had been effective during the last sowing. In order to evaluate the biological effectiveness, an absolute control - a treatment in which the insect was not controlled - was included.

Number of applications: Three doses were applied on the foliage, with seven days intervals.

Specification of the application equipment and spraying volume: The applications were carried out using a SWISS MEX manual spray backpack, with a previously calibrated fan nozzle. After the calibration, the spraying mean volume was $15 \mathrm{~L}$ for four repetitions.

Supplies used in this study: For this study, Adhefol was used as adhesive; the dose was $0.5 \mathrm{~mL} \mathrm{~L}^{-1}$ of water.

Evaluation method: A quantitative evaluation method was applied, recording the total number of live aphid organisms (nymphs, apterous adults, and winged adults) per

Table 1. Evaluated treatments and doses for the control of yellow aphid on sorghum.

\begin{tabular}{c|c|c}
\hline Treatments & Doses & Products \\
\hline 1 & $2 \mathrm{~mL} \mathrm{~L}^{-1}$ & Quillaja saponaria extract \\
\hline 2 & $4 \mathrm{~mL} \mathrm{~L}^{-1}$ & Quillaja saponaria extract \\
\hline 3 & $6 \mathrm{~mL} \mathrm{~L}^{-1}$ & Quillaja saponaria extract \\
\hline 4 & $10 \mathrm{~mL} \mathrm{~L}^{-1}$ & Calcium polysulfide \\
\hline 5 & $0.2 \mathrm{~mL} \mathrm{~L}^{-1}$ & Imidacloprid \\
\hline 6 & -- & Absolut test \\
\hline
\end{tabular}


$4 \mathrm{~cm}^{2}$ of leaf surface. The means of the counts carried out in four plants per treatment were used. The data obtained was subjected to an analysis of variance, using the SAS ver. 12.1 statistical software (SAS, 2012); given the highly significative difference between treatments, a Tukey test $(\alpha=0.05)$ was carried out to define the best treatments.

The ABBOTT Formula was used to calculate each treatment's biological effectiveness (EB), based on the number of live aphid organisms (Abbott, 1925):

$$
E B=(I T-i t / I T) 100
$$

where: $I T=$ severity in the untreated control; $i t=$ severity of the treatment.

\section{Sampling type, size, method, and frequency}

A quantitative evaluation was applied, recording the number of live Melanaphis sacchari per $4 \mathrm{~cm}^{2}$ of leaf: total number of nymphs, apterous adults, and winged adults per $4 \mathrm{~cm}^{2} /$ total number of sampled leaves.

The sample size comprised 16 leaves per treatment (four leaves per experimental unit), randomly collected from the useful plot. One sampling was carried out before the application of the treatments and three samplings were carried out — six days apart from each other- after the applications.

\section{RESULTS AND DISCUSSION}

\section{Effect of Quillaja saponaria on the number of $M$. sacchari nymphs and adults}

Before the treatments were applied, an evaluation was carried out in all experimental sorghum crop units, during which 137.75-157.5 yellow aphid nymphs and adults per 4 $\mathrm{cm}^{2}$ of leaf area were detected. Based on the statistical analysis, there were no significative statistical differences; therefore, all plots had the same initial conditions.

The aphid count was carried out after the treatments were applied. The results of the analysis of variance indicated that there was a highly significative difference between treatments. When the Tukey test (5\% significance) was applied, Q. saponaria extract treatments had the best results, while calcium polysulfide had the worst results. M. sacchari populations decreased up to $93 \%$ when Quillaja treatments were applied: the $6 \mathrm{~mL} \mathrm{~L}^{-1}$ water doses had the best numerical results, while the Imidacloprid treatment had a $37.5 \%$ effectiveness.

During the second sampling, the statistical analysis and the means comparison once again showed highly significative differences between the $Q$. saponaria, the absolute control, and the calcium polysulfide doses. Q. saponaria and Imidacloprid treatments kept aphid populations at a zero level (i.e., they had a 100\% biological effectiveness) (Figure 3).

During the third sampling, there was once again a highly significative difference between the $Q$. saponaria, the absolute control, and the polysulfide doses. $Q$. saponaria and Imidacloprid treatments kept aphid populations at a zero level (i.e., they had a $100 \%$ biological effectiveness) (Figure 4). 


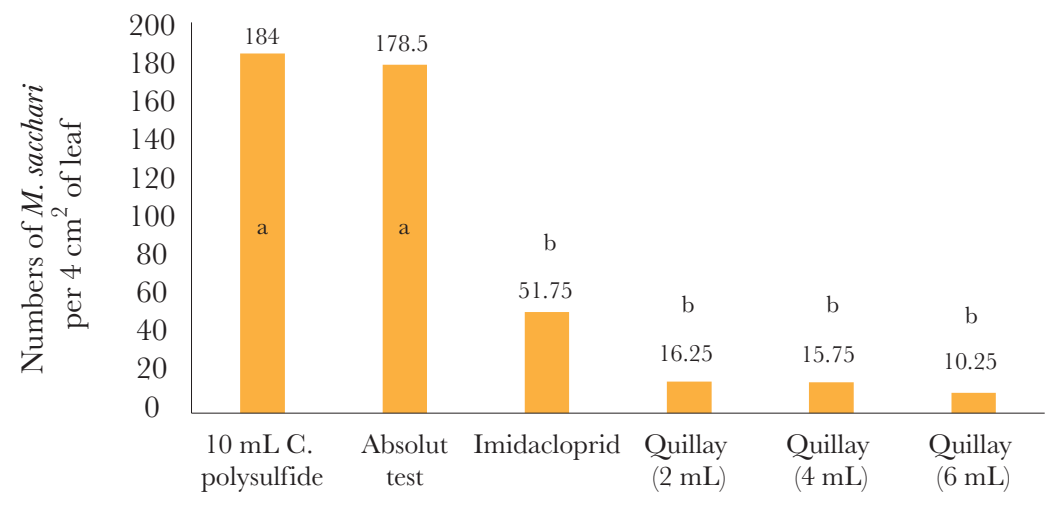

Figure 2. Number of yellow aphid nymphs and adults per $4 \mathrm{~cm}^{2}$ of leaf area, after the treatments were applied for the first time, in order to evaluate their biological effectiveness. Means with different letters in the columns indicate significant statistical differences between treatments $(\mathrm{P} \leq 0.05)$.

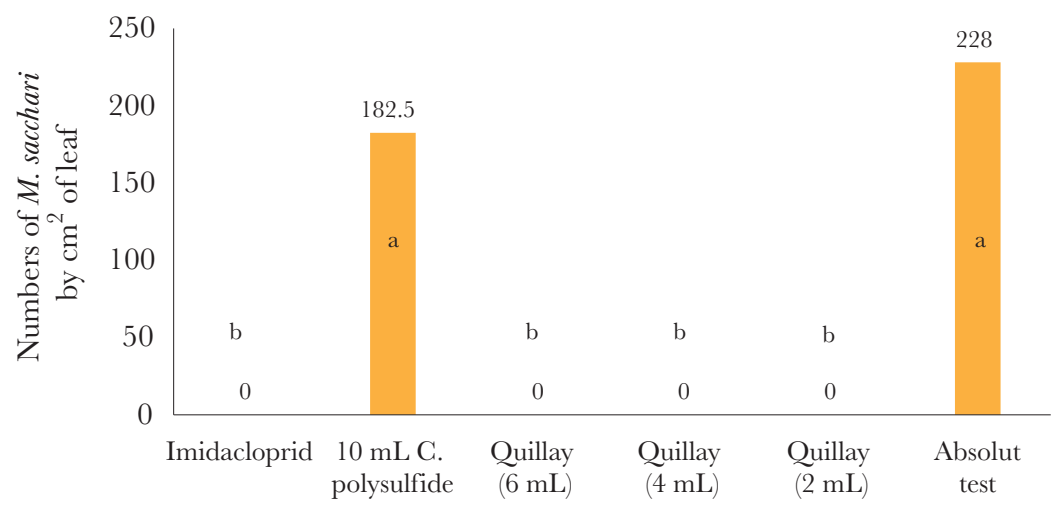

Figure 3. Number of yellow aphid nymphs and adults per $4 \mathrm{~cm}^{2}$ of leaf area, after the treatments were applied for the second time, in order to evaluate their biological effectiveness. Means with different letters in the columns indicate significant statistical differences between treatments $(\mathrm{P} \leq 0.05)$.

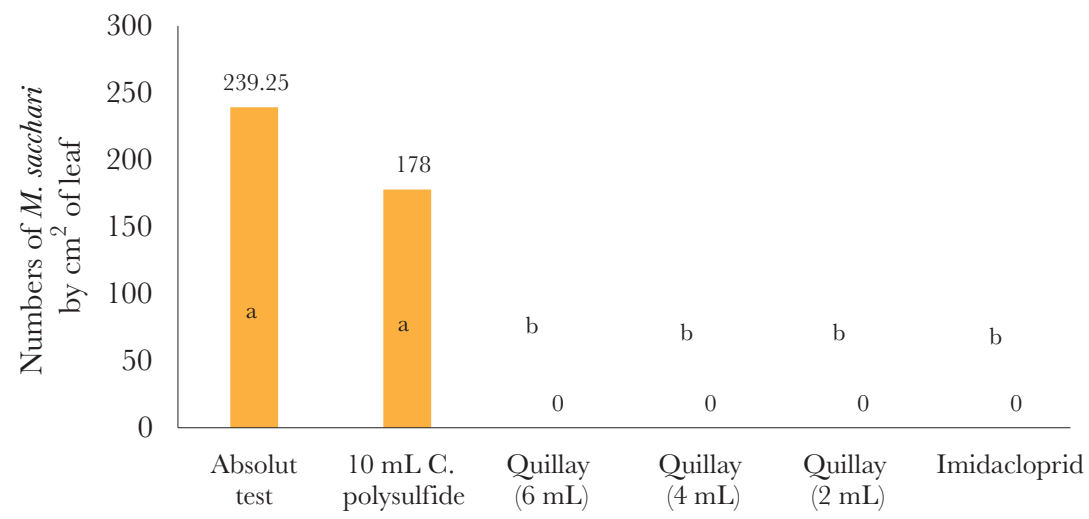

Figure 4. Number of yellow aphid nymphs and adults per $4 \mathrm{~cm}^{2}$ of leaf area, after the treatments were applied for the third time, in order to evaluate their biological effectiveness. Means with different letters in each column indicate significant statistical differences between treatments $(\mathrm{P} \leq 0.05)$. 
According to the first sampling, the biological effectiveness of the treatments indicates that Quillaja saponaria extract treatments, with 6-, 4-, and 2- $\mathrm{mL} \mathrm{L}^{-1}$ water doses had 93, 89, and 89\% effectiveness, respectively, while Imidacloprid had a $62.5 \%$ effectiveness.

During the second and third samplings, the Quillaja saponaria extract samples, with 6-, 4-, and $2-\mathrm{mL} \mathrm{L}^{-1}$ water doses, had a $100 \%$ biological effectiveness, while Imidacloprid also had a $100 \%$ effectiveness.

Figure 5 shows the biological effectiveness percentage of the treatments evaluated in this study against Melanaphis sacchari, after the third aphid count for the third and last application.

\section{Phytotoxicity evaluation}

Phytotoxicity was recorded in sorghum plants - particularly in young leaves and their whorls - during the three evaluations; however, the application of the treatments used in this study did not have a phytotoxic effect.

\section{CONGLUSIONS}

From the first application, treatments based on Quillaja saponaria extracts, with 6-, 4-, and $2-\mathrm{mL} \mathrm{L}^{-1}$ water doses, had 93, 89, and 89\% effectiveness against the yellow sorghum aphids (Melanaphis sacchari), respectively, while Imidacloprid had a $62.5 \%$ effectiveness. The third application of the Quillaja saponaria doses applied in this study, with 6-, 4-, and $2-\mathrm{mL} \mathrm{L}^{-1}$ water, had a $100 \%$ biological effectiveness, while Imidacloprid had a $100 \%$ effectiveness. None of the treatments used in this study showed any of the phytotoxicity symptoms that affect sorghum crops.

\section{REFERENGES}

Abbott, W. S. (1925). A method of computing the effectiveness of an insecticides. Journal of Economic Entomology, 18: $265-267$.

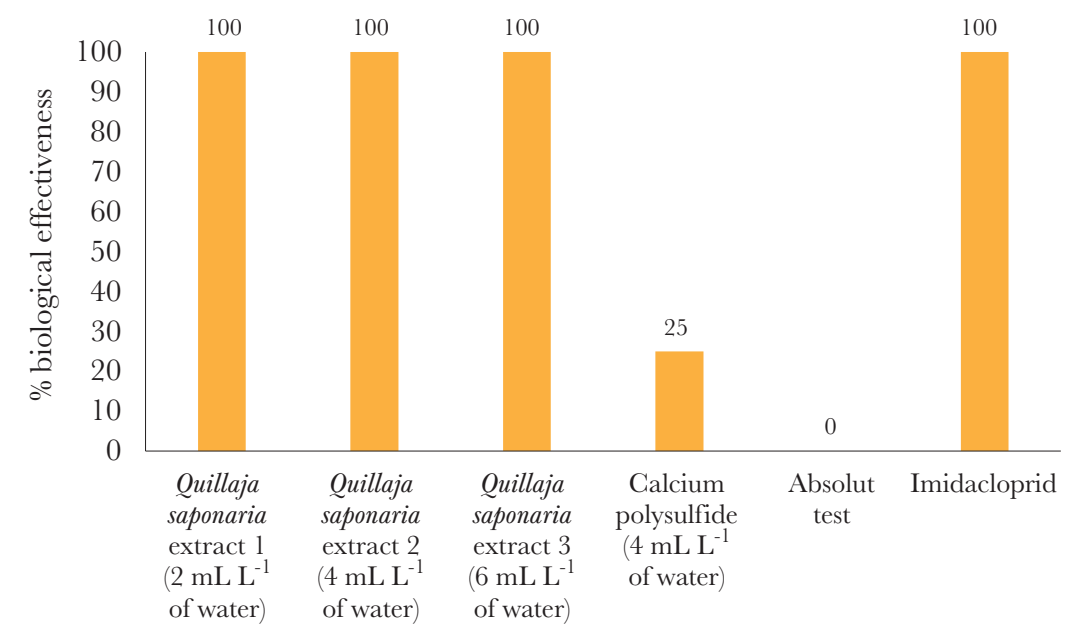

Figure 5. Biological effectiveness of Quillaja saponaria for the control of the nymphs of the yellow sorghum aphid (Melanaphis sacchari). 
Aranda-Lara, U., López-Benítez, A., Flores-Naveda, A., Zamora-Villa, V. M., Rodríguez-del-Bosque, L. A., Rooney, W. L. (2019). Susceptiblity of sorghum hybrids to the sugarcane aphid, Melanaphis sacchari, in Central Mexico. Southwestern Entomologist, 44(3): 771-774. https://doi.org/10.3958/059.044.0322

Blackman, R. L., Eastop, V. F. (2015). Aphids on the world's plants: an online identification and information guide (Adobe Digital Editions version).

Correa, C., A. Martínez. (2013). Antecedentes silvícolas y tecnológicos de Quillaja saponaria Mol. Productos forestales no madereros del bosque nativo en Chile. http://www.pfnm.cl /paqtecnologicos/quillay/ informacion_quillay.pdf Consultado el 28 de mayo de 2018.

Gallou, A., Serna-Domínguez, M.G., Berlanga-Padilla, A.M., Ayala-Zermeño, M.A., Mellín-Rosas, M.A., Montesinos-Matías, R., Arredondo-Bernal H.C. (2016). Species clarification of Isaria isolates used as biocontrol agents against Diaphorina citri (Hemiptera: Liviidae) in Mexico. Fungal Biology, 120: 414423.

Peña-Martínez, R., Muñoz, A. L., Ramos, G., Terrón, Y. R. (2015). Listado de plantas hospedantes del complejo Melanaphis sacchari/sorghi (Hemiptera: Aphididae), registros internacionales y potenciales en México. Entomología Mexicana, 2: 582-587.

Rodríguez Del Bosque, L.A., Terán, A.P. (2015). Melanaphis sacchari (Hemiptera: Aphididae): A new sorghum insect pest in Mexico. Southwestern Entomologist, 40(2): 433-434.

Rodríguez-del-Bosque, L. A., Garza-Cedillo, R. D., Ortíz-Chairez, F. E. (2018). Damage by Melanaphis sacchari reduces sorghum forage quality and feed consumption by cattle, sheep, and goats. Southwestern Entomologist, 43(3): 791-793.

SAS Institute Inc. (2012). SAS/STAT ${ }^{\circledR} 12.1$ User's Guide. Cary, NC: SAS Institute Inc. Cary, North Carolina, USA. 5136 p.

SENASICA (Servicio Nacional de Sanidad, Inocuidad y Calidad Agroalimentaria). (2014). Pulgón amarillo Melanaphis sacchari (Zehntner). Ficha técnica No.43.

Setokuchi, O., Muta, T. (1993). Ecology of Aphids on Sugarcane III. Relationship between alighting of aphid vectors of sugarcane mosaic virus and infecting in fields. Julio 1, 2017. (Oshima Branch, Kagoshima Agricultural Experiment Station, Naze, Kagoshima 894, Japan). Japanese Journal of Applied Entomology and Zoology, 37: 11-16.

SIAP (Sistema de Información Agroalimentaria y Pesquera). (2018). Sistema de Información Agroalimentaria de Consulta. Secretaría de Agricultura, Ganadería, Desarrollo Rural, Pesca y Alimentación, Sistema de Información Agroalimentaria y Pesquera. México.

Singh, B. U., Padmaja, P. G. and Seetharama, N. (2004). Biology and management of the sugarcane aphid, Melanaphis sacchari (Zehntner) (Homoptera: Aphididae), in sorghum: a review. Junio 20, 2017. Crop Protection, 23: 739-755.

Zehntner, L. (1897). Overzicht van de Ziekten van het Suikerriet op Java del. Archief voor de Java-Suikerindustrie, 5: 525-575. 